\title{
CURRENT ECOMOMICAL, SOCIAL ASPECTS OF HEALTH TECHNOLOGIES FOR PRETERM BIRTH AND REAL WORLD DATA OF DRUG PRESCRIPTIONS IN UKRAINE
}

\author{
(C) N. M. Maksymovych'1, O. M. Zalis'ka ${ }^{1}$, I. H. Mudrak ${ }^{2}$ \\ Danylo Halytskyi Lviv National Medical University ${ }^{1}$ \\ M. Pyrohov Vinnytsia National Medical University ${ }^{2}$
}

\begin{abstract}
Summary. Improving the quality of life and health of pregnant women and their rational pharmacotherapy are the main objectives of WHO. Ukraine occupies 72 place in terms of motherhood in the world.

We have analyzed and compared the national and international reports, guidelines on requirements for treatment and prevention of preterm birth. We analyzed the real world data of the frequency of drug prescriptions using ABC / VEN analysis based on medical records about drug prescriptions for pregnant women, diagnosed according to ICD-10 - O47.0. We found that the most common in A group were drugs for 7 INN (14.58 \% of total allocations) and the essential drugs was only sodium chloride, which indicated that not enough rational use of funds of patients.

We studied the evidence data about progesterone for effective treatment of PB. Therefore, that is important to optimize pharmaceutical care for pregnant women and rational use of medicines for effective pharmacotherapy of PB according to current health technologies.
\end{abstract}

Key words: pregnancy, preterm birth, health technology, real world data, drug prescriptions, progestin.

Introduction. According to the report «State of the World's Mothers 2014. Saving Mothers and Children in Humanitarian Crises" (was prepared by International Society "Save the Children") state Ukraine has 72 place (total - 178 states) in the world, depending on conditions of motherhood, such as rates of maternal health, educational, economic and political status of women and children). Other countries, such as Belarus has 26, Poland - 29, China - 61 place in this ranking [24].

Preterm birth (PB) is a serious medical, economical and social problem. This pathology is quite common among women in low-income countries, but in countries with high level, for example in the United States, that is also a significant problem. According to the $\mathrm{WHO}$ newsletter (2016) the rate of PB is over $60 \%$ in Africa and South Asia [27, 28]. The global World Prematurity Network, which includes organizations from Europe, Africa, Australia, China, Latin America, Canada, United States, has the main task to improve care and quality of life of premature infants [25].

According to data of M. Delnold (2015) the prevalence of $P B$ is $5-10 \%$ in Europe [6]. In Ukraine, there is still no official data on PB. Last data was published in 2008 , it showed the prevalence $12-46 \%$ and morbidity $-4.0-4.5$ $\%$ in 2014 [ 7, 13]. Pharmaceutical aspects of pregnant women in the hospital and using ABC VEN analysis were studied. Some aspects of pharmacoeconomic analysis «cost-effectiveness» for treatment of threatened abortion were elaborated in Ukraine [22].

Research methods. The aim of this article was to analyze the economical, social aspects of $\mathrm{PB}$ in the world and Ukraine. Also, we studied the real world data on prescribing of drugs for the pregnant with threatened $P B$, and determined a financial cost for therapy, using $A B C /$ VEN-analysis and the effectiveness rates according to evidence data for progestogens for $\mathrm{PB}$ treatment. We used content-analysis for recommendations, ABC/VEN analysis for drug prescriptions, systematic review of data.

Results and discussion. According to WHO Preterm Birth, defined as birth before 37 weeks of gestation, is the single most important determinant of adverse infant outcomes, in terms of survival and quality of life.. There are sub-categories of preterm birth, based on gestational age: extremely preterm (less 28 weeks), very preterm (28-32 weeks), moderate to late preterm (32-37 weeks) [26, 27]. Globally, it is the leading cause of perinatal and neonatal mortality and morbidity.

WHO published the new "Recommendations on interventions to improve preterm birth outcomes" in 2015. This guideline was developed using standard operating procedures which can improve the chances of survival and health outcomes for preterm infants. The recommendations include the evidence-based health technologies provided to the mother - for example steroid injections before birth, antibiotics when her water breaks before the onset of labour, and magnesium sulfate to prevent future neurological impairment of the child. As well as interventions for the newborn baby - for example thermal care (e.g. kangaroo mother care when babies are stable), safe oxygen use, other treatments, and the Cochrane systematic reviews were used primarily.

ISSN 2312-0967. Фармацевтичний часопис. 2016. № 4 
Every year for nearly 15 million babies are born preterm (before 37 weeks), and this number is rising. Preterm birth complications are the leading cause of death among children under 5 years of age, responsible for nearly 1 million deaths due to complications of preterm birth in 2015. Globally, prematurity is the leading cause of death in children under 5 years. And in almost all countries with reliable data, preterm birth rates are increasing. Many survivors face a lifetime of disability, including learning disabilities and visual and hearing problems. Also $75 \%$ of them could be saved with current, cost-effective health technologies.

Data indicated across 184 countries, the rate of preterm birth ranged from $5 \%$ to $18 \%$ of babies born. In low-income countries, $50 \%$ of the babies born at or below 32 weeks ( 2 months early) die due to a lack of feasible, cost-effective health technologies, such as warmth, and basic care for infections and breathing difficulties. In high-income countries, almost all of these babies survive.

According to the data of British premature baby support charity Bliss, about one in eight babies, or 80000 a year, are born prematurely, of these, 17000 need intensive care in UK. Among the children born very prematurely ( 22 to 27 weeks), they found that mortality rates among boys and girls were 5.3 and 9.7 times higher in early childhood. In late childhood boys were 7.0 times more likely to die than other children. The most surprising result was the high age in these boys and girls where increased mortality was registered [18].

Premature infants have an increased risk of dying in late childhood compared with healthy babies,they are significantly less likely to have children themselves. Mothers who were premature are more likely to give birth early as well. Several conditions can lead to premature delivery, including multiple pregnancy, gestational diabetes, pre-eclampsia or a stressful events, but about $30 \%$ of premature births happen for no apparent reasons $[5,18,19,21,23]$.

Since 2004 the International Working Group to study issues and prevention of $\mathrm{PB}$, that is Preterm Birth International Collaborative (PREBIC) was established. In 2014 in Denmark the First European Congress «Spontaneous premature labor» and the second International symposium of PREBIC was held [19].

In May 2012 report "Born too soon. The global action report on preterm birth" was published. The authors were 45 international experts from 11 countries with support of 50 organizations. This document consists of 6 sections, four of which are devoted to using of good safe health technologies during pregnancy [11].

One of the latest protocols to improve treatment and prevention $\mathrm{PB}$ are the $\mathrm{WHO}$ Recommendation (WHO recommendations on interventions to improve preterm birth outcomes, 2015) [27], NICE, 2015 (Preterm labour and birth) [21]. In Ukraine there were approved the Orders of Ministry of Health dated 31.12.2004 № 676, dated 03.11.2008 № 624, № 782 of 29.12.2005 on the requirements for health technologies during pregnancy and preterm birth [13 -15].

We ccompared the requirements for treatment of preterm birth in these recommendations and protocols, the results are given in Table 1 :

Our task was to analyze 102 medical records of pregnant women which diagnosed with PB (ICD10: - 047.0)/ These patients were hospitalized in the gynecology department of Lviv Regional Hospital in 2016, January-June. We founded that 62 pregnant women were the first-time birth, 40 were second-time, and the mean age was 27.3 years.

It was established that for PB treatment was prescribed 75 trade names of drugs, corresponding to 46 INN of drugs and 2 dietary supplements. Most frequently pregnant women were receiving these drugs top 10 in Figure 1.

In total, 689 prescriptions were made that on average was 6.75 drugs per pregnant, which indicated polypharmacy.

Using the $A B C$ analysis, we evaluated the design prescriptions of drugs, distributing drugs into three groups depending on their consumption. Was determined that the value of drugs, the average retail cost of packaging on September 2016. The analysisof PB schemes revealed that the group included 7 drugs from $A$ group for the INN (14.58\% of total prescriptions), which are the most costly drugs. In the group $C$ is 11 and includes 30 names on drugs INN, whose share of prescriptions was $22.9 \%$ and $62.5 \%$, respectively (Table. 1 ).

The analysis showed that among the drugs of group A weree selected such subgroups LS: G03 "Hormones of sexual glands and the preparations, used for the pathology of the sexual sphere", B05 - "Blood substitutes and perfusion solutions", A11 - "Vitamin", A03 - "Drugs used in functional gastrointestinal disorders", G02 - "Other gynecological medicines", N07- "Other drugs acting on the nervous system». The largest share are sub V05 - a 26 appointments with B05X B and 68 appointments of B05X A, as well as preparations subgroup $\mathrm{G} 03$ and $\mathrm{A} 11$ - 89 appointments and 70 respectively.

The highest cost was in group of progestogen drugs, and that were 10 trade names, of which 5 were in dosage forms for vaginal use, two dosage forms were in injectable and oral forms. Prescriptions of drugs of national producers amounted to $20 \%$ of all prescriptions.

Next task was to analyze the evidence based pharmacy data on the effectiveness of progestogens. Because these drugs are prescribed most often for private drug therapy according to the analysis of medical records lists. We searched the evidence data in PubMed. We founded the evidence of effectiveness for vaginal progesterone for use in women with singleton pregnancy and a short cervix [14, 17]. Internal use of 17a-hydroxyprogesterone kapronat appropriate for

ISSN 2312-0967. Pharmaceutical review. 2016. № 4 
Table 1. Analysis of the requirements for prescribing for preterm birth

\begin{tabular}{|c|c|c|c|}
\hline \multicolumn{2}{|l|}{ Document, year } & Group and/or drug & $\begin{array}{l}\text { Level of } \\
\text { recommendation }\end{array}$ \\
\hline \multicolumn{4}{|c|}{ Corticosteroids } \\
\hline \multirow[t]{6}{*}{ WHO, 2015} & \multicolumn{2}{|r|}{ For women, which have a risk of PB from 24 to 34 weeks and other requirements } & Strong \\
\hline & \multicolumn{2}{|r|}{$\begin{array}{l}\text { For women which PB will be inevitable within } 7 \text { days of treatment, including in } \\
\text { the first } 24 \text { hours }\end{array}$} & Strong \\
\hline & \multicolumn{2}{|r|}{$\begin{array}{l}\text { For women with premature rupture of amniotic membranes and the lack of signs } \\
\text { of infection }\end{array}$} & Strong \\
\hline & \multicolumn{2}{|r|}{$\begin{array}{l}\text { Not recommended for women with a planned cesarean section at a late stage of } \\
\text { prematurity }(34-36+6 \text { weeks })\end{array}$} & Middle \\
\hline & \multicolumn{2}{|r|}{$\begin{array}{l}\text { It's recommended for women with hypertensive disorders during pregnancy, } \\
\text { with up - and gestational diabetes who are at risk of PB }\end{array}$} & Strong \\
\hline & \multicolumn{2}{|r|}{ The first drug is Dexamethasone or Betamethasone, $24 \mathrm{mg}$ individual doses $\mathrm{i} / \mathrm{m}$. } & Strong \\
\hline Ï NICE, 2015 & \multicolumn{2}{|r|}{$\begin{array}{l}\text { It's recommended for women with high risk or premature rupture of membranes } \\
\text { in the period } 23-26+6 \text { weeks; } 24-25+6 \text { weeks; } 26-33+6 \text { weeks; } 34-35+6 \text { weeks } \\
\text { vaginal. Repeated courses are only in some cases (the interval since the end of } \\
\text { last year, gestational age, birth opportunity for } 48 \text { hours). }\end{array}$} & Not specified \\
\hline \multirow{3}{*}{$\begin{array}{ll}\text { Orders } & \text { of } \\
\text { Ministry } & \text { of } \\
\text { Health } & \text { of } \\
\text { Ukraine } & \end{array}$} & \multicolumn{2}{|r|}{$\begin{array}{l}\text { The use of Dexamethasone and Betamethasone is prescribed with doses and } \\
\text { course of treatment }\end{array}$} & Evidence level A \\
\hline & \multicolumn{2}{|r|}{ Not recommended for repeated courses } & Not specified \\
\hline & \multicolumn{2}{|r|}{ When there is a current manifestation of severe infection not used } & Not specified \\
\hline \multicolumn{4}{|c|}{ Tocolytics } \\
\hline WHO, 2015 & & $\begin{array}{l}\text { Not recommended for women with a risk of fatal PB; to improve the outcomes } \\
\text { in newborns }\end{array}$ & Middle \\
\hline NICE, 2015 & & $\begin{array}{l}\text { Nifedipine is recommended for women at risk in the period } 24-25 \text { weeks, } \\
26-33 \text { weeks vaginal. When contraindicated, then use the Oxytocin receptor } \\
\text { antagonists, is not recommended beta-mimetics }\end{array}$ & Not specified \\
\hline $\begin{array}{l}\text { Orders of Ministry } \\
\text { Health of Ukraine }\end{array}$ & & - & - \\
\hline \multicolumn{4}{|c|}{ Magnesium sulfate } \\
\hline WHO, 2015 & & $\begin{array}{l}\text { It's recommended for women who are at risk of inevitable PB to } 32 \text { weeks of } \\
\text { pregnancy; to prevent cerebral palsy in children }\end{array}$ & Strong \\
\hline NICE, 2015 & & $\begin{array}{l}\text { It'is recommended for infants and for women who are at risk or PB possibility } \\
\text { of them within } 24 \text { hours. in the period } 24-29+6 \text { weeks.vaginal, 30-33+6 } \\
\text { weeks, the scheme and doses are for pharmacotherapy }\end{array}$ & Not specified \\
\hline $\begin{array}{l}\text { Orders of Ministr } \\
\text { of Health of Ukrain }\end{array}$ & & It's indicated that no PB prevents and increased postnatal mortality & Not specified \\
\hline \multicolumn{4}{|c|}{ Progesteron } \\
\hline WHO,2015 & & - & - \\
\hline NICE, 2015 & & $\begin{array}{l}\text { For women, which were a history of spontaneous PB or between } 16-34 \\
\text { weeks, and 16-24 weeks vaginal. it was shown that cervical length less than } \\
25 \mathrm{~mm} \text {., as well as for women without a history of PB and with a short cervix }\end{array}$ & Not specified \\
\hline $\begin{array}{l}\text { Orders of Mini } \\
\text { of Health of Ukra }\end{array}$ & & - & - \\
\hline
\end{tabular}

women with a singleton pregnancy in history were PP [8]. Effective pharmacotherapy for the presence of a pregnant woman bleeding in the first trimester [9]. Dydrogesterone has more advantages compared with vaginal progesterone in women who became pregnant via IVF [10], and also reduces the risk of miscarriage in women with suspected potential. Article 2016 shows that the effectiveness of progesterone $(30 \mathrm{mg})$ is for the prevention of severe preeclampsia pregnant women at high risk $[14,25]$. Not recommended for primary prevention private use 17 $\alpha$-hydroxyprogesterone kapronat and vaginal progesterone forms in multiple pregnancies, and 17a-hydroxyprogesterone kapronat - women with multiple pregnancies with a short cervix. [8] Also, supplementation of progesterone in the first 12 weeks of pregnancy is not an effective way to prevent recurrent miscarriages [18]. However, research on the effectiveness of the pregnant women are held, also studied the impact on perinatal mortality, as final conclusions are difficult to make.

ISSN 2312-0967. Фармацевтичний часопис. 2016. № 4 


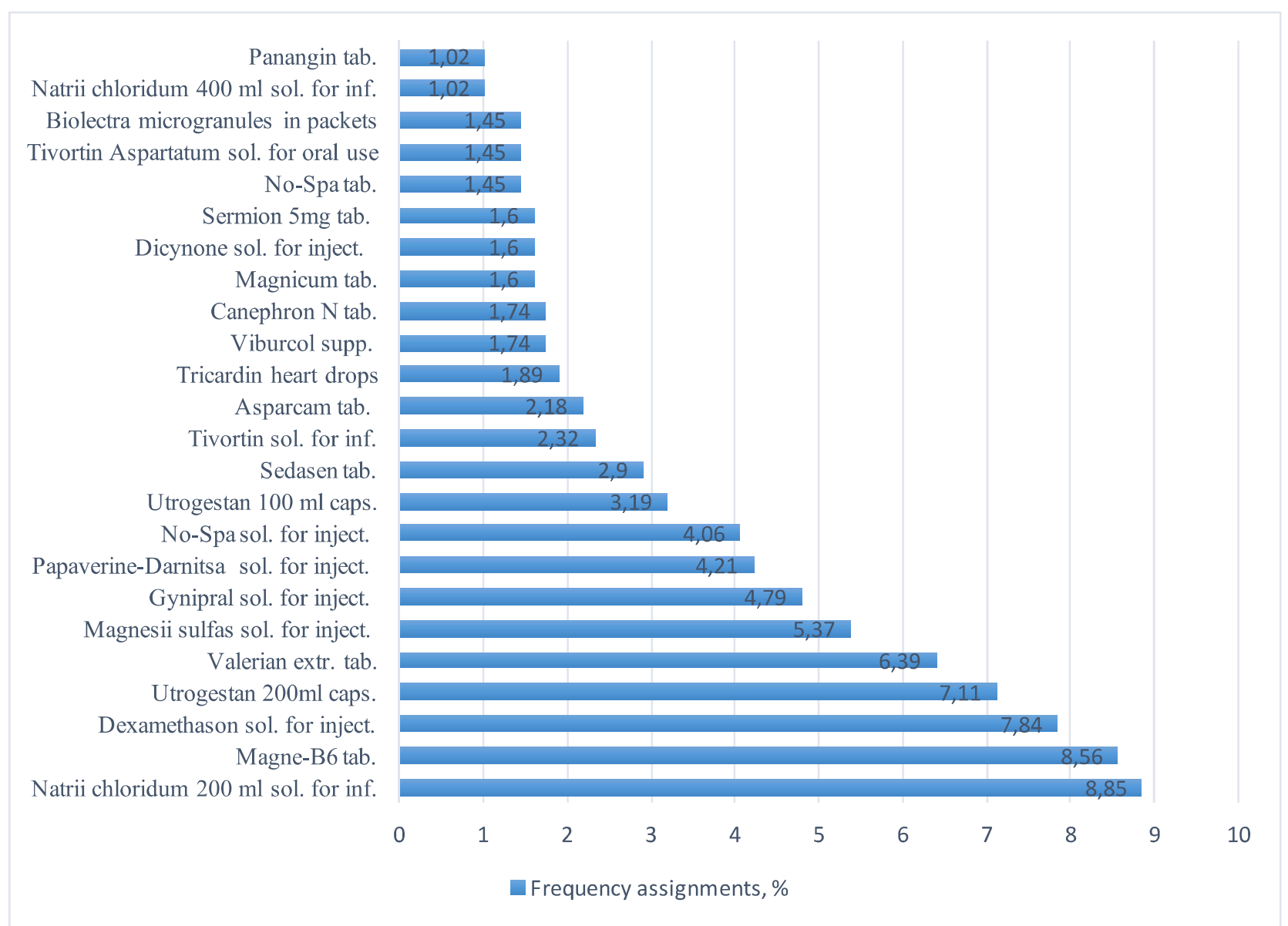

Figure 1. Frequency analysis of drug prescriptions for preterm birth (part)

For efficient and effective use of funds held by us VEN-analysis of consumption of medicines. This analysis divides drugs into three categories depending on their importance for the treatment of certain diseases: $\mathrm{V}$ - vital, E - necessary, N - minor, the importance of taking such drugs is questionable. The distribution of drugs to the appropriate category we conducted using a formal approach; if the drug was in the State logbook drug release 8 [5] and the National List of Essential medicines [6], then attributed to the drug group $\mathrm{V}$. When the drug was only one of these lists, then - in group E, in the absence of drugs in these documents - group $\mathrm{N}$ (tabl.2).

It was established, that according to a retrospective analysis of medical records the drug costs at the lowest purchase prices were 75354.25 UAH, the cost per one patient was $740 \mathrm{UAH}$ in average.

The VEN analysis showed that 12 drugs on INN were formed a Vital group, but the group of A / V entered only one drug, it's a sodium chloride. The largest number in the group $\mathrm{C}$ were 9 drugs, though some of them, such as magnesium sulfate, nifedipine, there are in these documents as a preparations for tocolytic therapy. The share of essential drugs is $43.8 \%$ (21 drugs on INN, and the non-essential are $31.3 \%$ (15 drugs on INN).

Thenextstepwas to analyze a data regarding evidencebased pharmacy on drug as progestogens. This group is often prescribing for pharmacotherapy PB according to our analysis of medical records. We used the results of the latest evidence-based data that is presented in

Table 2. $A B C$ - analysis of the consumption of drugs at risk of preterm birth

\begin{tabular}{|c|c|c|c|}
\hline Group ABC & Number of drugs on INN & Consumption, UAH & The share of expenditure (\%) \\
\hline A & 7 & 60751.44 & 80.62 \\
\hline B & 11 & 10749,5 & 14.27 \\
\hline C & 30 & 3853.31 & 5.11 \\
\hline Total & 48 & 75354.25 & 100.00 \\
\hline
\end{tabular}

ISSN 2312-0967. Pharmaceutical review. 2016. № 4 
searching network PubMed. Evidence-based data about progesterone for vaginal application for women with singleton pregnancy and a short cervix are presented $[2,9]$. Intravenous using of 17a-hydroxyprogesterone capronate is appropriate for women with a singleton pregnancy in PB history [1]. Effective implementation of pharmacotherapy for the presence of a pregnant woman bleeding in the first trimester [9]. Dydrogesterone has more advantages compared with vaginal progesterone in women who became pregnant via IVF [26], and also reduces the risk of miscarriage in women with suspected potential. In 2016 was published the results that showed the effectiveness $(30 \mathrm{mg})$ for the prevention of severe preeclampsia pregnant women at high risk $[12,17]$.

Now it not recommended for primary prevention use of 17a-hydroxyprogesterone capronate and vaginal progesterone forms in multiple pregnancies, and 17a-hydroxyprogesterone capronate for women with multiple pregnancies with a short cervix [8] Also, supplementation of progesterone in the first 12 weeks of pregnancy is not found an effective method of prevention of repeat abortions isn't known [18]
However, research on the effectiveness of even being pregnant and also studied the impact on perinatal mortality, so definitive conclusions difficult to do. For effective use we made VEN analysis. It makes it possible to distribute the drugs into 3 categories depending on their importance for the treatment of this disease: V - vital, E - essential, N - non-essential, the importance of these drugs are questionable. The distribution of drugs to the appropriate category performed using a formal approach based on the presence of drugs at the same time in the State Formulary 8 edition [14], the National List of Essential medicines [10], while the drug belonged to the group $\mathrm{V}$. When the drug was only one of the above document then was in the group $E$, in the absence of drug in these documents was in group N (Table 3).

The proportion of essential drugs was $43.75 \%$ (21 drugs on INN), and the non-essentials were $31.25 \%$ (15 drugs on INN), such as Probiz Femina and Yodofol belonged to the group $\mathrm{C} / \mathrm{N}$. So these prescriptions are need to correct for optimization of efficacy and safety of PB.

Table 3. Results of ABC / VEN analysis of drug prescribing for pregnant women with threatened PB (part of study)

\begin{tabular}{|c|c|c|c|c|}
\hline \multirow{2}{*}{ ATC Code } & \multirow{2}{*}{ INN or common name of drug } & \multicolumn{2}{|c|}{ Cost } & \multirow{2}{*}{ ABCNEN } \\
\hline & & $\mathrm{UAH}$ & $\%$ & \\
\hline G03D A04 & Progesterone & 32953.84 & 43.73 & $\mathrm{~A} / \mathrm{E}$ \\
\hline B05X B01 & Arginine hydrochloride & 9625.32 & 12.77 & $\mathrm{~A} / \mathrm{E}$ \\
\hline A11E C & Magne-B6 & 7681.12 & 10.19 & $\mathrm{~A} / \mathrm{N}$ \\
\hline B05XA03 & Natrii chloridi & 3146.55 & 4.18 & $\mathrm{~A} / \mathrm{V}$ \\
\hline A03A D02 & Drotaverine & 2837.47 & 3.77 & $\mathrm{~A} / \mathrm{E}$ \\
\hline G02C A05 & Hexoprenaline & 2612.61 & 3.47 & $\mathrm{~A} / \mathrm{E}$ \\
\hline N07XX10 & Cytoflavin & 1894.53 & 2.51 & $\mathrm{~A} / \mathrm{N}$ \\
\hline C 04A E 02 & Nicergoline & 1716.25 & 2.28 & $\mathrm{~B} / \mathrm{E}$ \\
\hline G01A C05 & Dequalinii chloride & 1327.81 & 1.76 & $B / E$ \\
\hline R05X & Viburcol & 1316.1 & 1.75 & $\mathrm{~B} / \mathrm{N}$ \\
\hline H02A B02 & Dexamethasone & 1156.68 & 1.53 & $\mathrm{~B} / \mathrm{V}$ \\
\hline A03A D01 & Papaverine & 920.05 & 1.22 & $\mathrm{~B} / \mathrm{E}$ \\
\hline G04BX50** & Canephron $\mathrm{N}$ & 855.08 & 1.13 & $\mathrm{~B} / \mathrm{N}$ \\
\hline \multirow[t]{2}{*}{ A12CC10. } & Magnesium oxide & 776.23 & 1.03 & $\mathrm{~B} / \mathrm{N}$ \\
\hline & Other 4 drugs & 2681.30 & 3.56 & $\begin{array}{c}\mathrm{B} / \mathrm{N} \\
3-\mathrm{B} / \mathrm{E}\end{array}$ \\
\hline C05C A03 & Diosmin & 559.02 & 0.74 & $\mathrm{C} / \mathrm{N}$ \\
\hline J01F A07 & Josamycin & 428.16 & 0.57 & $\mathrm{C} / \mathrm{E}$ \\
\hline A05AX10** & Cynara scolymus* & 356.18 & 0.47 & $\mathrm{C} / \mathrm{N}$ \\
\hline A12CC55** & Magnesium aspartate + Potassium aspartate & 322.6 & 0.43 & $\mathrm{C} / \mathrm{E}$ \\
\hline B05X A05 & Magnesium sulfate & 255.71 & 0.34 & $\mathrm{C} / \mathrm{V}$ \\
\hline J01D D08 & Cefiximum & 211.64 & 0.28 & $\mathrm{C} / \mathrm{V}$ \\
\hline \multirow[t]{2}{*}{ G01AX10** } & Chlorhexidine & 201.15 & 0.27 & $\mathrm{C} / \mathrm{V}$ \\
\hline & Other 23 drugs & 1518.85 & 2.03 & $\begin{array}{l}6-\mathrm{C} / \mathrm{V} \\
9-\mathrm{C} / \mathrm{E} \\
8-\mathrm{C} / \mathrm{N}\end{array}$ \\
\hline
\end{tabular}

ISSN 2312-0967. Фармацевтичний часопис. 2016. № 4 


\section{Conclusions.}

1.Preterm birth is a huge economical, medical and social problem in the world, especially in low in-come countries. It was established that current Ukrainian clinical protocols include the treatment and prevention of $\mathrm{PB}$ have a need for a good revision because the WHO, NICE published a new evidence-based recommendations for health technologies of PB in 2015.

2. We determined that treatment for $P B$ threat appointed 75 trade names of drugs, including 46 for INN and 2 supplements. The average number of prescriptions for a pregnant woman shown polypharmacy. The cost of drug therapy is for one patient average $740 \mathrm{UAH}$.

3.Using $A B C$ / VEN analysis showed that the group $A$ included 7 drugs for the INN, the group $B$ and $C$ included 11 and 30 drugs, respectively.

4.Progestines have a good evidence data, but it need to determine the less expensive scheme/ drugs for the treatment and prevention of $\mathrm{PB}$ using pharmacoeconomic analysis results in Ukraine.

\section{Literature}

1. A randomised controlled double-blind clinical trial of 17-hydroxyprogesterone caproate for the prevention of preterm birth in twin gestation (PROGESTWIN): evidence for reduced neonatal morbidity / J. Awwad, I. M. Usta, G. Ghazeeri [et al.] // BJOG An International Journal of Obstetrics \& Gynaecology. 2014. - Vol. 122, №1. - P. 71-79.

2. A randomized trial of progesterone in women with recurrent miscarriages / A. Coomarasamy, H. Williams, E. Truchanowicz [et al.] // N. Engl. J. Med. - 2015. Vol. 373, №22. - P. 2141-2148.

3. Analysis of the follow-up results concerning pregnancy, delivery and infants after assisted reproductive technique with GnRH-a for luteal support / W. Zhou, Y. Pan, Y. Zhuang [et al.] // Zhonghua Fu Chan Ke Za Zhi. - 2016. - Vol. 51, №1. - P. 31-35.

4. Born too soon The global action report on preterm birth [Electronic resource] - Access: http://www.who.int/pmnch/ media/news/2012/201204_borntoosoon-report.pdf

5. Centers for Disease Control and Prevention [Electronic resource] - Access: https://www.cdc.gov/ reproductivehealth/maternalinfanthealth/pretermbirth.htm

6. Delnord M. What contributes to disparities in the preterm birth rate in European countries? / M. Delnord, B. Blondel, J. Zeitlin. // Curr. Opin. Obstet. Gynecol. - 2015. - Vol. 27, №2. - P. 133-142.

7. Kaminsky V. The tocolytic therapy opportunities / V. V. Kaminsky, S. Zhuk. - Women's Doctor. F - 2008. №6. - 2008. - P. 3.

8. Premature birth has long-term effects [Electronic resource] - Access: https://www.theguardian.com/ science $/ 2008 / \mathrm{mar} / 26 /$ medicalresearch.children

9. Martinez de Tejada B. Prevention of preterm birth with vaginal progesterone in women with preterm labor: which are the evidences? [Electronic resource] / B. Martinez de Tejada, V. Othenin-Girard, O. Irion - Access: - https://www. ncbi.nlm.nih.gov/pubmed/26672179

10. $\mathrm{MOH}$ on 31.12.2004 number 676 «On approval of clinical protocols for obstetric and gynecological care» [Electronic resource] - Access: http://www.moz.gov.ua/ua/ portal/dn_20140324_0205.html

11. Mohamad Razi Z. Review on role of progestogen (dydrogesterone) in the prevention of gestational hypertension / Z. Mohamad Razi, A. Schindler // Horm Mol Biol Clin Investig. - 2016. - Vol.27, №2. - P. 73-76.

12. National List of Essential Medicines First Edition (November 2016) adapted from the basic list of

essential medicines WHO 19th edition, 2015 [Electronic resource] - Access: https://drive.google.com/file / d / OBWMIN7nHqX2LdIBSY3hRcXQzT1k / view

13. National, regional, and worldwide estimates of preterm birth rates in the year 2010 with time trends since 1990 for selected countries: a systematic analysis and implications / H. Blencowe, S. Cousens, M. Z. Oestergaard [et al.] // Lancet. - 2012. - №379. - P. 2162-2172.

14. O 'Brien J. M. Prevention of preterm birth with vaginal progesterone or 17-alpha-hydroxyprogesterone caproate: a critical examination of efficacy and safety / J. M. O 'Brien, D. F. Lewis. // Am. J. Obstet. Gynecol. - 2016. -Vol. 214, №1. - P. 45-56.

15. Order of $\mathrm{MOH}$ dated 14. 03. 2016 p. № 183 «On Approval of the eighth issue state form of medicines and ensuring its availability» [Electronic resource]. - Access: http://www.moz.gov.ua/ua/portal/dn_20160314_0183.html 16. Order of $\mathrm{MOH}$ dated 03.11.2008 №624 «Ōn approval of clinical protocols on obstetrical and gynecological care» [Electronic resource] - Access: http://www.moz.gov.ua/ua/ portal/dn_20081103_624.html

17. Order of $\mathrm{MOH}$ dated 29.12.2005 N 782 «On approval of clinical protocols for obstetric and gynecological care» [Electronic resource] - Access: http://www.moz.gov.ua/ua/ portal/dn_20051229_782.html

18. Paddock C. Progesterone supplements do not help women with recurrent miscarriages. [Electronic resource] / C. Paddock // Medical News Today. - 2015. - Access: http://www.medicalnewstoday.com/303214.php.

19. Preterm Birth International Collaborative [Electronic resource] - Access: www.prebic.org/

20. Preterm birth time trends in Europe: a study of 19 countries / J. Zeitlin, K. Szamotulska, N. Drewniak [et al.] // BJOG. - 2013. - Vol.120. - P. 1356-1365.

21. Preterm labour and birth [Електронний ресурс] // NICE. - 2015. - Режим доступу: https://www.nice. org.uk/guidance/ng25/resources/preterm-labour-andbirth-1837333576645.

22. Shunko E. E. Strategic areas of care to newborns in Ukraine / E. E. Shunko // Neonatology, perinatal medicine and surgery. - Vol. 4. - №3 (13). - 2014. - P. 11-14.

23. Socioeconomic inequalities in very preterm birth rates / L. K. Smith, E. S. Draper, B. N. Manktelow [et al.] // Arch. Dis. Child. Fetal. Neonatal. Ed. - 2007. - Vol. 92. - P. 11-14. 24. State of the World's Mothers 2014 Saving Mothers and Children in Humanitarian Crises [Electronic resource] -

ISSN 2312-0967. Pharmaceutical review. 2016. № 4 
Access: http://www.savethechildren.org/att/cf/\%7B9def2ebe10ae-432c-9bd0-df91d2eba74a\%7D/SOWM_2014.PDF 25. The World Prematurity Network [Electronic resource] Access: http://prembaby.org.au/worldprematurityday/ 26. Tskhay V. B. Successful prevention of preeclampsia in a high-risk pregnancy using progestogen dydrogesterone: a clinical case. / V. B. Tskhay, N. M. Kovtun, A. E. Schindler // Horm Mol Biol Clin Investig. - 2016. - Vol. 27, №2. - P. 85-88.
27. WHO recommendations on interventions to improve preterm birth outcomes [Electronic resource] - Access: http://apps.who.int/iris/ bitstream/10665/183037/1/9789241508988 eng.pdf?ua=1 28. World Health Organization Preterm birth [Electronic resource] // Fact sheet Reviewed November 2016 -Access: http://www.who.int/mediacentre/factsheets/fs363/en

\title{
СУЧАСНІ ЕКОНОМІЧНІ, СОЦІАЛЬНІ АСПЕКТИ ТЕХНОЛОГІЙ ОХОРОНИ ЗДОРОВ'Я ТА АНАЛІЗ РЕАЛЬНИХ ДАНИХ ПРИЗНАЧЕНЬ ЛІКІВ ДЛЯ ФАРМАКОТЕРАПІЇ ПЕРЕДЧАСНИХ ПОЛОГІВ
}

\author{
Н. М. Максимович ${ }^{1}$, О. М. Заліська' ${ }^{1}$, І. Г. Мудрак ${ }^{2}$ \\ Львівський національний медичний університет імені Данила Галицького ${ }^{1}$ \\ Вінницький національний медичний університет імені М. І. Пирогова
}

Резюме: поліпшення якості життя, здоров'я вагітних жінок та лікування передчасних пологів $є$ основними цілями директив ВООЗ. Україна займає 72 місце в рейтингу за рівнем забезпечення материнства в світі.

Нами вивчені у порівняльному плані рекомендації ВООЗ, 2015 міжнародні рекомендації, накази МОЗ України щодо лікування передчасних пологів (ПП) та виявлено певні відмінності, що вимагає оновлення вітчизняних протоколів.

Ми проаналізували реальні дані частоти призначень лікарських засобів при ПР з використанням ABC/VEN-aналізу на основі 102 історій хвороб вагітних жінок з діагнозом відповідно до МКX-10 - О47.0. Встановлено, що для лікування загрози ПП призначалися 75 торгових назв (46 МНН лікарських засобів та 2 БАД). Сумарно було 689 призначень ліків, що в середньому складає 6,75 препарата на одну вагітну жінку, що свідчить про поліпрагмазію. Виявлено, що в групі А найбільш часто призначаються препарати 7 MHН (14,58 \% від загального обсягу) і основним лікарським засобом є натрію хлорид, що свідчить про недостатньо раціональне використання фрінансових коштів пацієнтів.

Встановлено, що сумарно витрати на призначені Л3 при ПР становили 75354,3 грн, а витрати на фрармакотерапії 1 пацієнтки були в середньому 740,2 грн.

Нами проаналізовані доказові дані про призначення прогестеронів для лікування ПР. Встановлено, що найбільш есрективним для лікування ПП за даними доказової фрармації $є$ прогестерон у лікарській фрормі для вагінального прийому для жінок 3 короткою шийкою матки, а дигістростерон - при застосуванні допоміжних репродуктивних технологій

Доцільною є оптимізація фрармацевтичної допомоги вагітним при ПР за даними доказової фрармації та призначення економічно ефективної фрармакотерапії для раціоналізації витрат пацієнтів.

Ключові слова: вагітність, передчасні пологи, оцінка технологій охорони здоров'я, аналіз реальних даних, призначення ліків, прогестини.

\section{СОВРЕМЕННЫЕ ЭКОНОМИЧЕСКИЕ, СОЦИАЛЬНЫЕ АСПЕКТЫ ТЕХНОЛОГИЙ ЗДРАВООХРАНЕНИЯ И АНАЛИЗ РЕАЛЬНЫХ ДАННЫХ ПОТРЕБЛЕНИЯ ЛЕКАРСТВ ПРИ ФАРМАКОТЕРАПИИ ПРЕЖДЕВРЕМЕННЫХ РОДОВ}

\section{Н. М. Максимович', О. Н. Залиская ${ }^{1}$, И. Г. Мудрак ${ }^{2}$}

Львовский национальный медицинский университет имени Данила Галицкого ${ }^{1}$ Винницкий национальный медицинский университет имени Н. И. Пирогова

Резюме: улучшение качества жизни и здоровья беременных женщин и их рациональной фрармакотерапии являются основными целями ВОЗ. Украина занимает 72 место в рейтинге уровня обеспечения материнства в мире.

Мы проанализировали и сравнили национальные и международные рекомендации, руководящие принципы, касающиеся требований к лечению и профилактике преждевременных родов (ПР). Мы проанализировали реальные данные частоты назначений лекарственных средств с использованием ABC / VEN-анализа на основе историй болезней о назначении лекарств для беременных женщин, диагностированных в соответствии с МКБ-10 O47.0.

Установлено, что для лечения ПР назначалось 75 торговых наименований (46 МНН лекарственных средств и 2 БАД). Суммарно было 689 назначений лекарств, что составляет в среднем 6,75 препарата на одну беременную

ISSN 2312-0967. Фармацевтичний часопис. 2016. № 4 
женщину и свидетильствует о полипрагмазии. Установлено, что в группе А наиболее назначаемыми были препараты по $7 \mathrm{MHH}(14,58$ \% от общего объема) и основным лекарственным средствам является по потреблению натрия хлорид, что свидетельствует о недостаточно рациональном использовании фринансовых средств пациентов.

Установлено, что суммарно расходы на назначенные лекарства при ПР составили 5354,3 грн, а расходы на фрармакотерапию 1 пациентки были в среднем 740,2 грн.

Нами проанализированы доказательные данные о назначении прогестерона для лечения ПР. Установлено, что наиболее эффрективным В лечении ПР по данным доказательной фрармации является прогестерон в лекарственной фрорме для вагинального приема для женщин с короткой шейкой матки, а дигистростерон - при применении вспомогательных репродуктивных технологий. Необходимым является оптимизация фрармацевтической помощи беременным при ПР по данным доказательной фрармации и назначения экономически эффрективной фрармакотерапии для рационализации расходов пациенток.

Ключевые слова: беременность, преждевременные роды, оценка технологий здравоохранения, анализ реальных данных, назначение лекарств, прогестины. 